\title{
Relocations: Diaspora, Travel, Migrancy
}

\author{
Ellen McWilliams
}

Stephen Dedalus's insistence in A Portrait of the Artist as a Young Man (I9I6) that 'the shortest way to Tara was via Holyhead' is James Joyce's most dramatic reminder that Irish literature is dominated by stories of departure and return, of journeys, real or imaginary, by which the Irish writer comes to claim a place in the world and all the better negotiate a relationship with home. ${ }^{\mathrm{I}}$ The work of the Irish Literary Revival of the late nineteenth and early twentieth centuries and the avant-garde experiments of Irish modernism were determined by the siren call of different places; W. B. Yeats moved between London, Dublin, and Sligo, while the mapping of a newly vivid relationship between Ireland and Europe is at the heart of the work of Joyce and Samuel Beckett. This pattern is one that is repeated with new resonances in the later decades of the twentieth century and into the new millennium. During this period of Irish literary history, a fresh understanding of Ireland's relationship with its diaspora emerged along with a body of work that sought to engage with the realities of emigration in the 1980s and the emergence of new narratives of Irish migration during the Celtic Tiger years of the I990s and beyond. The result was the rise of a new kind of Irish writing about migration and return, journeying, and exploration, and an accompanying public and academic discourse that sought to illuminate more fully the story of the Irish abroad.

This essay is especially interested in how Irish writing from 1980 to the present responds to the differently inflected stories of migration and diaspora. Long a figure of anxiety, the Irish emigrant - from the nineteenth-century famine victim to the migrant of the economically depressed Ireland of the I950s - haunts the work of more recent Irish writers as the story of Irish emigration is recovered and re-animated in literary culture. The narrative of the Irish abroad is also foregrounded in the fashioning of a new idea of the Irish literary canon, one that expands outwards beyond the limits of the nation to engage with writers of the 
diaspora. At the same time, for some writers, the possibilities of creative escape through reaching for horizons beyond more familiar and dominant Irish landscapes offer a means of transcending the limits of a narrative dominated by Ireland's colonial history and the Irish Troubles, north and south of the border.

For Fintan O'Toole, 'emigration and exile, the journeys to and from home, are the very heartbeat of Irish culture. To imagine Ireland is to imagine a journey'. ${ }^{2}$ And, yet, for all the importance of this symbol of the 'journey', the history of Irish emigration has only fully emerged as a significant preoccupation among literary critics in recent decades. History and the social sciences have led the way in the development of the fields of Irish migration and Irish diaspora studies, but over the course of the last twenty years, literary studies has begun to keep pace. ${ }^{3}$

\section{Migration and the Irish Diaspora in the I980s and 1990 s}

In The Lie of the Land: Irish Identities (1997), O'Toole collates a series of dramatic statistics about the social impact of emigration in Ireland in the twentieth century:

Emigration has been the single biggest fact in the 75-year history of the Irish State. Only half those born in Ireland in the early 1930s, for instance, were still living there thirty years later. The rate of emigration dropped rapidly in the I960s, but picked up again in the late I970s and early 1980s, so that the 1996 census showed that nearly 20 per cent of those born in 1970 were by then living in some other country. ${ }^{4}$

If the most dominant narratives of Irish emigration focused on the history of Irish exile in Britain and the United States, Jim Mac Laughlin notes that the 1980 and 1990 os were marked by a government response that at its core seemed to suggest that increasingly 'Irish emigrants were moving to benign taxfields and fields of opportunity in Europe. 5 The equation of emigration and 'opportunity' found particularly contentious expression in Minister for Foreign Affairs Brian Lenihan's insistence on the necessity of emigration as a safety valve for the Irish economy and his now infamous exasperated pronouncement in 1987: 'We can't all live on a small island.'

In 1993, reflecting on the centrality of migration as a centripetal force in Irish cultural life, Joseph O'Connor concluded:

Emigration is as Irish as Cathleen Ní Houlihan's harp, yet it is only since the sixties and the generation of Edna O'Brien that Irish writers have written about the subject at first hand. [... It has been taken as read that Exile is an 
important theme in Irish writing, like The Big House or The Catholic Church. But if it is, it's an inconsistent and entirely intermittent preoccupation. ${ }^{7}$

A previous generation of writers had already begun to address this lacuna by articulating the Irish writer's experience of exile at mid-century. Edna O'Brien's The Country Girls trilogy, the first instalment of which appeared in 1960 , served as a landmark study of the lives of young Irish women in the west of Ireland, Dublin, and London, and it is part Bildungsroman, part dissection of the insular conservatism of post-independence Ireland. O'Brien would go on to spend most of her life outside of Ireland and her memoirs Mother Ireland (1976) and Country Girl (20I2) offer vivid accounts of the complexities of a relationship with a home place that, most certainly in the early chapters of her creative life, was openly hostile to her writing. John McGahern's The Leavetaking (1974) reflects upon the impossibility of staying in Ireland for the Irish artist and looks back to his own experience of being forced to leave the country in the I960s after the publication of his novel The Dark (1965), which was banned for its candid depiction of young adult sexuality. Furthermore, McGahern's short stories and his early unpublished novel The End or The Beginning of Love, written between 1957 and 1961, return time and again to the experience of Irish navvies in Britain, in part a refraction of his own time as a labourer on London building sites in the I950s.

O'Brien, McGahern, and other writers of their generation continued this excavation of post-independence Ireland into the I980s and I990s, while these decades also saw the emergence of a new generation of writers less interested in remembering the past and more concerned with confronting the present-time experience of emigration. The i980s exodus led to a new kind of writing about leaving home brought about in part by the scale of emigration in these years. Joe Cleary records that 'by 1987 emigration in the Republic had risen to rates estimated at approximately 30,000 to 40,000 people per annum, something not witnessed since the bleak decade of the I950s'. The most determined response to these developments came in the form of Dermot Bolger's Ireland in Exile: Irish Writers Abroad (1993), which set out to engage directly with the lived experiences that lay behind these extraordinary statistics. Bolger's poetry collection Internal Exiles (1986) took up this theme, but his novel The Journey Home (I990) gives powerful voice to a new generation and their experience of emigration. Set in Dublin, the novel examines the different forms that exile takes and is interested in 'internal migration' patterns from rural Ireland to 
Dublin as well as the more familiar narrative of migration to Britain and the United States. ${ }^{9}$ Exile also serves as a metaphor for the estrangement between generations, as the main character Hano's father is bound by memory to his 'homeland' of Co. Kerry, while Hano struggles with the realities of contemporary Dublin. His father's displacement from rural Kerry to suburban Dublin is imagined as a culture shock akin to arriving in a new country: 'They planted trees in the image of their lost homeland, put down potato beds, built timber hen-houses. [...] When the radio announcer gave the results of the provincial Gaelic matches the backs would straighten, neighbours reverting to county allegiances as they slagged each other. ${ }^{\text {'IO }}$ The apparent inevitability of emigration is a key concern of the novel, and it draws a direct comparison between past and present: 'He remembered the farewells in Murtagh's, no longer cardboard suitcases and cattle boats, but green cards and holiday visas. [...] As the airport posters proclaimed, they were the young Europeans, fodder now not just for factory floors but for engineering and computer posts. ${ }^{\text {II }}$

Like Bolger, Joseph O'Connor responded directly to the emigration crisis of the r 1980 s in his early novel Cowboys and Indians and shortstory collection True Believers (both 199I). In the story, 'Last of the Mohicans', a character denounces 1980 os Ireland as a 'glorified tax haven for rich tourists and popstars. A cultural backwater that time forgot. He said no one who ever did anything stayed in Ireland'. ${ }^{\text {I2 }}$ A coming-of-age story set in the 1980s, Cowboys and Indians charts Eddie Virago's picaresque adventures in London. He meets Marion Mangan, a young woman from a small town in Donegal and the traumatic secret at the heart of the novel - Marion's flight to London for an abortion - gradually reveals itself. In a lighter vein of the novel, O'Connor satirises the place of the Irish in London yuppie culture as Eddie contemplates what it might mean to become a NIPPIL (New Irish Professional Person in London).

Emma Donoghue's early work also features an awareness of how emigration shaped Irish life in these decades. In Hood (I995), the material realities of emigration are reflected in the minutiae of the text: 'Across the road was a tacky religious goods shop and an advice centre, its window featuring pamphlets called Think Before You Emigrate and Coping with London.' ${ }^{\text {'3 }}$ Her short story 'Going Back', collected in Bolger's Ireland in Exile, is Donoghue's most direct intervention in confronting Ireland's homophobia, as the main character describes herself as feeling 'more of an exile for twenty years in Ireland than I ever have in the twelve I've been out of it'. ${ }^{\text {I4 }}$ 
In the same period, London Irish playwright Martin McDonagh emerged as an important figure determined to write back to his Irish origins in particularly vivid ways. McDonagh's plays set in the West of Ireland revisit the dramatic territory of the writers of the Irish Literary Revival with new purpose. For example, The Cripple of Inishmaan (1997) is set against the backdrop of the filming of Robert Flaherty's Man of Aran (1934), a sentimental exploration of life on the Aran Islands, but gives the islanders free voice in their right of reply to Flaherty's vision. In one scene a young woman vents her ire at having been sidelined in the making of the film and denounces Flaherty's project in no uncertain terms: 'I think I might go pegging eggs at the film tomorrow. The Man of Aran me arsehole. "The Lass of Aran" they could have had, and the pretty lass of Aran. Not some oul shite about thick fellas fecking fishing. ${ }^{\text {'I }}$ McDonagh has more recently gone on to carve out a place for himself on the international scene as director of films such as In Bruges (2008) and Three Billboards Outside Ebbing, Missouri (2017), but his early work as a playwright constitutes a highly self-conscious and charged letter home from the diaspora.

The I980s and I990s were especially important decades for capturing the testimonies of the Irish in Britain and, most particularly, Irish women in Britain, who as late as 1995 remained, in the words of one historian, the 'great unknown' of Irish emigrant history. ${ }^{16}$ In the same period, two important voices emerged across the water in the work of Maude Casey and Moy McCrory, both of whom addressed what McCrory characterises as the silence of second-generation Irish people in Britain. ${ }^{17}$ Set in the Irish community in Liverpool, McCrory's collection The Water's Edge (1985) explores the tensions and fractures between generations. A poignant story in the collection, entitled 'Prize Giving', captures one such moment of estrangement: 'Sometimes he could not understand how Siobhan was their daughter. Her ways were so very different. She was so English, a foreigner to her parents. To her, Mayo was just a postmark on a card from cousins she did not know very well. ${ }^{\text {'18 }}$ Maude Casey's Over the Water (1987) is also concerned with such alienation as the teenage girl at the centre of the novel feels set apart by her parents' Irishness.

The experiences of Irish women migrants in this period command attention, not least because of the ways in which Irish women's lives and bodies were policed at home. Siobhán Kilfeather offers a striking summing-up of the circumscription of Irish women's lives at this time: 
In the I980s and I990s public debates over issues to do with privacy, reproductive rights and alternative sexualities were centred on a series of scandals in which print and broadcast media personalised the issues through sensationalised exemplary cases: the death in childbirth of I5-year-old Ann Lovett and her baby in 1984; the trial of Joanne Hayes for the murder of the Kerry babies in 1984; the decision of rape survivor Lavinia Kerwick to renounce anonymity and speak on a radio programme in $1990 .{ }^{19}$

Such public surveillance and regulation of Irish women's reproductive rights are addressed in a number of works concerned with what Ann Rossiter, in her anthology of testimonies of Irish women who were left no choice but to travel to England for an abortion during these decades, calls 'The Hidden Diaspora'. ${ }^{20}$ Evelyn Conlon's collection My Head Is Opening (1987) offers glimpses of Irish women's lives under the same conditions. In Conlon's short story 'Transition', a young woman becomes pregnant unexpectedly and escapes a doomed affair by leaving for England, a journey characterised by the juxtaposition of freedom and peril: 'She was now responsible, twenty-three, and learned. She had become a silent citizen, a fool. No. No, not that. A silenced citizen, away, with a destroyed life and name. A freed person - there was nothing left to lose. ${ }^{2 \mathrm{I}}$ William Trevor's novel Felicia's Journey (1994) tells of a similar journey to England as the eponymous heroine leaves home when she discovers she is pregnant in order to follow the father of her baby to Birmingham. She is abandoned by her homeland, another 'silent citizen', and left vulnerable and isolated in the unfamiliar territory of urbanindustrial Birmingham.

For Irish poets, the navigation of the journey between homeland and hostland has taken on a new purchase. Eavan Boland, whose work is so concerned with recovering lost histories and creating a space for the Irish woman poet, also turned her eye to the elided history of the Irish migrant. Her poem 'The Emigrant Irish' (1987) honours the story of Irish emigration and a diaspora too long ignored: 'Like oil lamps we put them out the back, $\|$ of our houses, of our minds. ${ }^{, 22}$ The same poem was one of the inspirations for President Mary Robinson's 1995 address to the Houses of the Oireachtas, 'Cherishing the Irish Diaspora', in which she called for a renewal of 'our love and remembrance on this island for those who leave it behind'. ${ }^{23}$ At times Boland directly addresses her own childhood experience of leaving Ireland for England, as in 'An Irish Childhood in England, 195I'. Yet her work travels across time and history - often fusing classical with Celtic mythology - and tracks her own movement as a poet and academic between Ireland, Britain, and America. This might be 
interpreted as a necessary vigilance about predetermined roles for the Irish woman poet on home soil, and as such exemplifies what Boland identifies as the ever-present need to evade the powerful 'imagery and emblem of the national muse'. ${ }^{24}$

\section{Emigrant Hauntings and the Rise and Fall of Celtic Tiger Ireland}

If Irish writing about journeying out into the world was marked by a concern with engaging with emigration as it played out in real time in the I980s and early I990s, then the unprecedented prosperity of the Celtic Tiger years in the I990s and 2000s, and the rise of immigration and return migration, led to a new kind of literary meditation on the past. In her study of Celtic Tiger literature, Susan Cahill argues that Anne Enright belongs to a new category of writer whose primary concern is to 'explore and question the dominant narratives that served to support the Irish state, particularly in relation to questions of genealogies and generations (maternal and otherwise), occluded histories, and the material bodies that are affected by such repressions'. ${ }^{25}$

One such 'occluded' history is the story of the emigrant, as the Irish writer began to offer a new kind of account of the history of Irish migration, a history that for Piaras Mac Éinrí had been for too long characterised by 'palpable public silence', ${ }^{26}$ and that for Fintan O'Toole (writing about the Irish in Britain) had been suppressed by a kind of cultural 'amnesia and evasion'. ${ }^{27}$ For O'Toole this coming to consciousness served as a particularly important counterpoint to the rise of anti-immigrant rhetoric in Celtic Tiger Ireland - as Ireland moved from being a country historically defined by emigration to an immigrant destination, it also became one characterised by what O'Toole diagnosed as an 'increasing tendency to see "Irish" and "immigrant" as opposed categories of humanity'. ${ }^{28}$ Sinéad Moynihan has explored the tectonic shifts that came about in this period and the way in which '(re)imagining Irish diasporic experience in the United States in various ways - particularly as it relates to Irish interactions with African Americans - became absolutely central to representations of multicultural Ireland during the Celtic Tiger years'. ${ }^{29}$

Different strands of Irish writing during the Celtic Tiger years as well as after the economic crash of 2008 , which saw a return to outward migration, continued to engage with overlooked narratives of the Irish diaspora. During this time, Irish writers in Britain negotiated between past and present experiences of migration with a new kind of vividness. In the poem 'To Those Who Have Inherited a Country' from his 2008 
collection, Slipping Letters Beneath the Sea, Birmingham-Irish poet Joe Horgan offers an especially resonant reply to the economic success of Celtic Tiger Ireland from the point of view of the Irish in Britain: 'If we'd known | we'd have stayed. | We could have lingered | outside your electronic gates, | built your crowded motorways, | instead of theirs.' ${ }^{30}$ This turn to history is taken up and expanded in Kit de Waal's most recent novel, The Trick to Time (2018), which is set, in part, among the Birmingham-Irish community in the I970s. In recent years the story of the London Irish has been explored in the documentary films Men of Arlington (20II) and Breaking Ground: The Story of the London Irish Women's Centre (2013), and in studies such as Tony Murray's London Irish Fictions: Narrative, Diaspora and Identity and Clair Wills's history The Best Are Leaving: Emigration and Post-War Irish Culture (2015), while Liam Harte's anthology The Literature of the Irish in Britain: Autobiography and Memoir (2009) is an ambitious compendium of life writing that reaches from 1725 to 2001 .

As the diaspora continued to write home via different media, on home territory these years were marked by a concern with stories of return and recovery as well as departure. In an interview Anne Enright described the process of addressing missing histories in the story of Ireland: 'We are bringing them all back home: it is not just recent emigrants who are returning to Ireland, but the dead, the lost, the long-ago disappeared. ${ }^{31}$ Enright's work from the ragos to 2000 s is deeply concerned with different kinds of departure and return, from the return home from London to Dublin in The Wig My Father Wore (1996) to the story of mistaken and reclaimed identity in What Are You Like? (2000). However, the most extended meditation on how Irish emigrants have been written out of the national tale appears in The Gathering (2007) via Veronica Hegarty's journey from Dublin to Brighton to repatriate the body of her dead brother, a traumatised figure who is all but abandoned by his family.

Other writers offered a more familiar story of the returnee during these years, in a reworking of a familiar figure in Irish literary culture: the emigrant who is drawn back to Ireland by personal crisis, family duty, or curiosity about the place they left behind. ${ }^{32}$ In Kate O'Riordan's The Memory Stones (2003), the main character is called home to Ireland from Paris to her daughter, a recovering drug addict, when she gets a call from a concerned neighbour. On her arrival back in Ireland she has to negotiate between her concern for her troubled daughter and her granddaughter and the freedom and autonomy of her life in France. This contemporary 
returnee narrative is held up against memories of stories told by her uncle of the Irish in England:

They'd talk and talk about going back, what they were going to do, who they were going to see. For weeks they'd be out of their heads from excitement and whiskey. Buying presents for brothers and sisters, half of John Lewis for their mothers. And then they'd get to Paddington to catch the boat train, wave their mates good-bye, slip into the nearest pub, get slaughtered and take the bus back to their lodgings to spend the next two weeks in a drunken stupor. ${ }^{33}$

Edna O'Brien's The Light of Evening (2006) explores a more sympathetic and conciliatory relationship between returnee and homeland through an epistolary exchange between the woman writer and her mother that revisits O'Brien's early work and attempts to establish new lines of communication between the Irish woman emigrant and her homeland.

\section{Transatlantic Affinities}

The narrative of Irish emigration to the United States remains the most pervasive and since the I980s a number of novelists have contributed to the consolidation of this mythology. Colum McCann's This Side of Brightness (1998) is set in New York in the early decades of the twentieth century and focuses, in part, on immigrants labouring on the New York subway system - the lives of Irish, Italian, and African American workers from the south intersect and intertwine across three generations. McCann's TransAtlantic (2013) is a more explicit literary engagement with Atlantic crossings by public figures, from Frederick Douglass to Senator George Mitchell. Joseph O'Connor's Star of the Sea (2002) is one of the bestknown and most celebrated navigations of the 'Irish Atlantic' in recent decades. ${ }^{34}$ But perhaps the most striking navigation of this terrain remains Colm Tóibín's Brooklyn (2009); published just after the economic crash of 2008 , it was especially attuned to the cultural implications of return migration to Ireland during the economic prosperity of the Celtic Tiger years, despite being set largely in 1950 os America. ${ }^{35}$

While the work of Irish-born writers shows a particular interest in recovering and re-purposing migrant narratives, the literature of the Irish diaspora has also gained new currency in the last forty years. In this, IrishAmerican writing has been especially significant and the publication of Charles Fanning's The Irish Voice in America: 250 Years of Irish-American Fiction in the early I990s was a landmark moment in Irish-American literary studies. The book follows a timeline from the eighteenth century 
to the twentieth-century and the work of writers such as Edward McSorley and James T. Farrell. ${ }^{36}$ In the same decade the writing of a number of Irish-American women writers came to prominence. While the recovery of the work of New Yorker writer Maeve Brennan, who was born in Ireland but spent most of her adult life in the US, represents one version of this history, writers such as Elizabeth Cullinan, Mary Gordon, and Alice McDermott began to give voice to a rapidly changing IrishAmerican culture in the decades after the Second World War.

If for the Irish-American writer there is a rich tradition to draw upon and resist in turn, the Irish writer in Canada tells a rather different story. In Brian Moore's The Luck of Ginger Coffey (1960), the hapless eponymous emigrant arrives in Canada and suffers a series of disappointments as his new life fails to launch. As part of the emergence of Irish-Canadian literature, women writers have been especially important in charting new kinds of transatlantic encounters. While Margaret Atwood's Alias Grace (1996) is perhaps the best-known contemporary novel about the Irish in Canada in the nineteenth century, the fiction of Irish-Canadian writer Jane Urquhart offers an extended meditation on Irish-Canadian history, from her early novel Away (1993), a story of flight from Ireland during the famine years, to The Night Stages (2015), a historical novel set in Ireland in the 1950s. The distant and recent history of the Irish in New Zealand and Australia has also begun to emerge in contemporary fiction, as in Coral Atkinson's The Love Apple (2005), Evelyn Conlon's famine novel Not the Same Sky (2013), and E. M. Reapy's post-crash novel Red Dirt (2016).

\section{Relocating the Contemporary Irish Writer}

The history of Irish migration and diasporic relations remain dominant critical frameworks for thinking about the relationship between the Irish writer and other spaces and places. At the same time, foreign settings and locations can themselves serve as a means of breaking new imaginative ground beyond the more familiar paradigms of the Irish literary tradition. In the case of the Northern Irish poet, this is partially informed by the challenge of engaging with the political violence and conflict on home ground and the importance of movement and perspective in bearing witness to the Troubles. For Seamus Heaney, this challenge was accompanied by the dilemma of seeing his work co-opted as British and by the need to move through 'the identity gears'. ${ }^{37}$ Wintering Out (1972) and North (1975) set a precedent for this interest in movement and identity as he locates the 'bog poems' at the heart of North in Iron-Age Danish 
Jutland, distant in both time and place from Troubles-era Ulster. London, like Derry and Dublin, emerges as an important writing location in Heaney's expansive geography, as suggested in the title poem of District and Circle (2006), an extended meditation on political violence set against the backdrop of the London underground.

In the essay 'The Irish Poet and Britain', Heaney ponders the particular dilemma of the Northern Irish poet and the inheritances of place:

And these things accumulated even more problematically in the mid-196os, when I had started to publish poems and began to be included in anthologies with titles like Young Commonwealth Poets and Young British Poets. Probably I could have gone on living and hesitating to speak had I gone on living in Northern Ireland and had the question of British versus Irish loyalties not mutated into the deadly complications of our more or less civil war. [. . . By 1983, my family and I had been resident for eleven years in the Irish Republic, although I should emphasize that when we moved, it was not in order to flee the violence but in order that I might take advantage of an offer of a house in Wicklow that was a kind of writer's retreat; anyhow, there we were, and in order to make a new coherence between where we were living and who and what I was, I had taken out an Irish passport. ${ }^{38}$

Other Northern Irish poets explore a different kind of fluidity and multiplicity of identity that destabilises some of the more familiar co-ordinates of Irish literary culture; in one strand of their work, these poets transcend the story of the nation as one defined by colonial and postcolonial conflict and divine creative possibilities for seemingly remote places. Such poetic nomadism serves a special purpose for poets whose work is so often read through the fixed lens of the politics of the Northern Irish Troubles - they find imaginative refuge in places and historical moments that untether their work from the more predictable critical paradigms that dominate discussions of Northern Irish writing. Examples include Paul Muldoon's American poems and investigations of Native American history in volumes such as New Weather (1973) and Meeting the British (1987), Derek Mahon's epistolary poems from his time in New York City in The Hudson Letter (1995), and Sinéad Morrissey's sequence of poems about Japan in Between Here and There (200I). The close identification of writers Justin Quinn with Prague and Julian Gough with Berlin is a reminder that the European metropolis is as much home to the Irish writer in the twenty-first century as its Hibernian equivalent.

A related strain in contemporary Irish fiction concerned with mobility and travel shows a greater preoccupation with journeys than origins or destinations. For instance, Anne Enright's The Pleasure of Eliza Lynch 
(2002) is a transnational historical adventure that takes in Paris, Paraguay, and Argentina while in Enright's The Green Road (2015) the global scattering of the family is presented as an inevitable fact of Irish life. Joseph O'Neill's Netherland (2008) is, in part, concerned with the stories of migration that comprise the history and cultural fabric of the United States, but it is also a contemporary novel in which the most significant geography is configured via Google Maps. Paula McGrath's Generation (2015) explores intertwined histories across time and moves between different cultures as a means of locating the story of Irish migration within a larger global framework. What these writers share is an interest in releasing the Irish experience of movement, travel, and journeying from the more immediately familiar narrative of loss and gain that so often accompanies writing about emigration and diaspora. The Irish writer's journey out into the world is, then, one that takes in the real histories and lived experiences of emigrant generations and the Irish diaspora as well as the possibilities of adventuring into new territory in the interests of pushing against the limits of the national imagination.

\section{Notes}

I. James Joyce, Seamus Deane, ed., A Portrait of the Artist as a Young Man (London: Penguin, 1992), p. 273.

2. Fintan O'Toole, The Ex-Isle of Erin: Images of a Global Ireland (Dublin: New Island, 1997), p. I57.

3. See, for example, Patrick Ward, Exile, Emigration, and Irish Writing (Dublin: Irish Academic Press, 2003); Liam Harte, The Literature of the Irish in Britain: Autobiography and Memoir: I725-200I (Basingstoke: Palgrave Macmillan, 2009); Sinéad Moynihan, 'Other People's Diasporas': Negotiating Race in Contemporary Irish and Irish-American Culture (Syracuse, NY: Syracuse University Press, 2013); Ellen McWilliams, Women and Exile in Contemporary Irish Fiction (Basingstoke: Palgrave Macmillan, 2013); Tony Murray, London Irish Fictions: Narrative, Diaspora and Identity (Liverpool: Liverpool University Press, 20I4); Moira Casey and Amanda Tucker, eds., Where Motley is Worn: Transnational Irish Literatures (Cork, Ireland: Cork University Press, 20I4); Enda Delaney and Ciaran O'Neill, eds., 'Beyond the Nation: Transnational Ireland', special issue of Eire-Ireland, 5I.I-2 (2016); Sinéad Wall, Irish Diasporic Narratives in Argentina: A Reconsideration of Home, Identity and Belonging (Oxford: Peter Lang, 2017); and Ailbhe McDaid, The Poetics of Migration in Contemporary Irish Poetry (Basingstoke: Palgrave Macmillan, 20I7).

4. Fintan O'Toole, The Lie of the Land: Irish Identities (London: Verso, 1997), p. xiv. 
5. Jim MacLaughlin, 'Introduction', in Jim Mac Laughlin, ed., Location and Dislocation in Contemporary Irish Society (Cork, Ireland: Cork University Press, I997), pp. I-36 (p. 3).

6. Brian Lambkin and Patrick Fitzgerald, Migration in Irish History, I607-2007 (Basingstoke: Palgrave Macmillan, 2008), p. 246.

7. Dermot Bolger, 'Introduction', in Dermot Bolger, ed., Ireland in Exile: Irish Writers Abroad (Dublin: New Island, I993), pp. II-I8 (p. I6).

8. Joe Cleary, "Misplaced Ideas"?: Colonialism, Location, and Dislocation in Irish Studies', in Clare Carroll and Patricia King, eds., Ireland and Postcolonial Theory (Cork, Ireland: Cork University Press, 2003), pp. I6-45 (p. I8).

9. Lambkin and Fitzgerald, Migration, p. 2 Io.

Io. Dermot Bolger, The Journey Home (London: Penguin, I99I), pp. 6-7.

II. Ibid., p. 47.

I2. Joseph O'Connor, 'Last of the Mohicans', in True Believers (London: Flamingo, 1992), pp. 3-13 (p. 7).

I3. Emma Donoghue, Hood (London: Penguin, I996), p. I89.

I4. Emma Donoghue, 'Going Back', in Bolger, ed., Ireland in Exile: Irish Writers Abroad, pp. I57-70 (p. 160).

15. Martin McDonagh, The Cripple of Inishmaan (London: Methuen, 1997), p. 5 I.

I6. Donald Harman Akenson, The Irish Diaspora: A Primer (Belfast: Institute of Irish Studies 1993), pp. I57-8.

17. Moy McCrory, "This Time and Now": Identity and Belonging in the Irish Diaspora: The Irish in Britain and Second-Generational Silence', in Christine Berberich, Neil Campbell, and Robert Hudson, eds., Land and Identity: Theory, Memory, and Practice (Amsterdam: Rodopi, 2012), pp. I65-90.

I8. Moy McCrory, 'Prize Giving', in The Water's Edge and Other Stories (London: Sheba, 1985), pp. I28-39 (p. 136).

19. Siobhán Kilfeather, 'Irish Feminism', in Joe Cleary and Claire Connolly, eds., The Cambridge Companion to Modern Irish Culture (Cambridge: Cambridge University Press, 2005), pp. 96-II6 (p. III).

20. See Ann Rossiter, Ireland's Hidden Diaspora: The 'Abortion Trail' and the Making of a London-Irish Underground, I980-2000 (London: Iasc, 2009).

2I. Evelyn Conlon, 'Transition', in My Head Is Opening (Dublin: Attic Press, I987), pp. 43-56 (p. 56).

22. Eavan Boland, Collected Poems (Manchester: Carcanet, I995), p. I29.

23. Mary Robinson, 'Cherishing the Irish Diaspora: An Address to the Houses of the Oireachtas' (1995). See McWilliams, Women and Exile in Contemporary Irish Fiction, p. I.

24. Eavan Boland, Object Lessons: The Life of the Woman and Poet in Our Time (Manchester: Carcanet, I995), p. I37.

25. Susan Cahill, Irish Literature in the Celtic Tiger Years 1990-2008: Gender, Bodies, Memory (London: Continuum, 20II), p. I9. 
26. Piaras Mac Éinrí, 'Introduction', in Andy Bielenberg, ed., The Irish Diaspora (Harlow, England: Pearson, 2000), pp. I-I5 (p. 3).

27. Fintan O'Toole, 'Forgotten Irish in UK Deserve Recognition', The Irish Times, I9 September 2000: www.irishtimes.com/opinion/forgotten-irish-inuk-deserve-recognition-I.IIO4433 [accessed I3 August 20I9].

28. Ibid.

29. Sinéad Moynihan, 'Other People's Diasporas', p. 3.

30. Joseph Horgan, Slipping Letters Beneath the Sea (Tralee, Ireland: Doghouse Books, 2008), p. 52.

3I. Anne Enright, 'Review of The Story of Chicago May by Julia O'Faolain', The Times, I January 2006: www.thetimes.co.uk/article/the-story-of-chicago-mayby-nuala-ofaolain-2m9vg7p256j [accessed 29 March 2019].

32. Sinéad Moynihan, Ireland, Migration and Return Migration: The "Returned Yank" in the Cultural Imagination, I952 to present (Liverpool: Liverpool University Press, 2019).

33. Kate O'Riordan, The Memory Stones (London: Simon \& Schuster, 2003), p. 177.

34. Sinéad Moynihan, 'Ships in Motion: Crossing the Black and Green Atlantics in Joseph O'Connor's Star of the Sea', Symbiosis: A Journal of Anglo-American Literary Relations, I2. I (2008), pp. 4I-58.

35. For a detailed analysis of the novel's engagement with discourses of Celtic Tiger and Post-Celtic Tiger Ireland, see Sinéad Moynihan, "We are where we are": Colm Tóibín's Brooklyn, Mythologies of Return and the Post-Celtic Tiger Moment', in Leslie Eckel and Clare Frances Elliott, eds., The Edinburgh Companion to Atlantic Literary Studies (Edinburgh: Edinburgh University Press, 2016), pp. 88-102.

36. Other studies of Irish-American writing include Marion R. Casey and J. J. Lee, eds., Making the Irish American: History and Heritage of the Irish in the United States (New York: New York University Press, 2006); Christopher Dowd, The Construction of Irish Identity in American Literature (London: Routledge, 20Io); Sally Barr Ebest, The Banshees: A Literary History of Irish American Women Writers (Syracuse: Syracuse University Press, 2013); and Tara Stubbs, American Literature and Irish Culture, I9I0-I955: The Politics of Enchantment (Manchester: Manchester University Press, 2013).

37. Seamus Heaney, 'Through-Other Places, Through-Other Times: The Irish Poet and Britain', in Finders Keepers: Selected Prose 197I-200I (New York: Farrar, Straus and Giroux, 2003), pp. 396-4I5 (p. 40I).

38. Heaney, Finders Keepers, p. 40I. 